\title{
Break the Negative Feedback Chains: Future Teachers Speak Up!
}

\section{Romper las cadenas de retroalimentación negativa: iLos futuros docentes hablan!}

\author{
Henry Sevilla-Morales and Roy Gamboa-Mena2* \\ Universidad Nacional de Costa Rica, Costa Rica \\ Universidad de Costa Rica, Costa Rica
}

\begin{abstract}
:
This study examines future teachers' theoretical reflections on Critical Incidents and how these link to Costa Rica's English teaching system. Participants included 30 senior college students from an English teaching program. Using narrative research techniques, the authors have concluded that: (1) spaces for reflection must be created in EFL so that students' voices are heard; (2) both instruction and assessment need to be tackled not from the native speaker angle but from the learner language perspective; and (3) because mistakes are both inherent to foreign language learning and an indicator of language development, more tolerance to learner errors needs to be exercised. The study proves relevant for language pedagogy and Applied Linguistics (AL) since it paves the way for further research, opens room for reflection and dialogue, and enhances our understanding of the issue at stake from a future-teacher standpoint.
\end{abstract}

Keywords: critical incidents; reflective writing; future English teachers; professional identity; negative feedback

\section{Resumen:}

Se evalúan las reflexiones teóricas de futuros profesores sobre incidentes críticos y su relación con la actualidad del sistema educativo costarricense. Los participantes fueron 30 estudiantes avanzados de una carrera en la enseñanza del inglés en Costa Rica. Con base en técnicas de investigación narrativa, se desvelan tres hallazgos principales: (1) es necesario crear espacios de reflexión en el aula de inglés como lengua extranjera a fin de considerar las voces de los estudiantes; (2) más allá de la perspectiva nativo-hablante, es preciso abordar la docencia y la evaluación desde la perspectiva del estudiante y (3)

1 Received: July 18th 2018/ Accepted: May 14th 2019

2 henrysevilla@gmail.com; gamboa.roy@gmail.com 
dado que los errores son inherentes al aprendizaje de una lengua extranjera y además indicadores de desarrollo lingüístico, es vital que los docentes ejerzan mayor tolerancia en torno a este caso. La investigación es relevante para el campo de la enseñanza de lenguas y la Lingüística Aplicada dado su potencial de generar futuras investigaciones, abrir espacios de reflexión y dialogo y facilitar una mejor comprensión del tema en cuestión desde la perspectiva de futuros docentes.

Palabras clave: incidentes críticos; escritura reflexiva; futuros docentes de inglés; identidad profesional; retroalimentación negativa

\section{Resumo}

Avaliam-se as reflexões teóricas de futuros professores sobre incidentes críticos e a sua relação com a atualidade do sistema educativo costarriquense. Os participantes foram 30 estudantes avançados de uma carreira no ensino do inglês na Costa Rica. Com base em técnicas de pesquisa narrativa, revelam três descobertas principais: (1) é necessário criar espaços de reflexão na aula de inglês como língua estrangeira com o fim de considerar as vozes dos estudantes; (2) mais além da perspectiva nativofalante, é preciso abordar a docência e a avaliação desde a perspectiva do estudante e (3) dado que os erros são inerentes à aprendizagem de uma língua estrangeira, e além de indicadores de desenvolvimento linguístico, é vital que os docentes exerçam maior tolerância em torno a este caso. A investigação é relevante para o campo do ensino de línguas e a Linguística Aplicada, dado o seu potencial de gerar futuras pesquisas, abrir espaços de reflexão e diálogo e facilitar uma melhor compreensão do tema em questão desde a perspectiva de futuros docentes.

Palavras clave: incidentes críticos; escritura reflexiva; futuros docentes de inglês; identidade profissional; retroalimentação negativa 


\section{Introduction}

7 he current paper follows up on Sevilla and Gamboa's 2017 study of critical incidents (CIs) and the configuration of future teacher's professional identities. In such paper, the authors aimed to "unveil the role that critical incidents and reflective writing play in the configuration of future EFL teachers' professional identities" (p. 233). The informants included 30 college students majoring in English teaching at the University of Costa Rica, who wrote and reflected on critical incidents that molded their English learning and teaching experiences. The researchers followed Freeman's (1998) four-stage process for data analysis and interpretation in the analysis of the results and arrived at three conclusions: "(1) spaces for reflection should be opened so that positive practices are kept and the negative can be dismantled, (2) reflective writing through critical incidents is an effective way to realize professional and other social identities, and (3) reflective writing through critical incidents is a bridge through which dialogue can be initiated amongst all educational actors (p. 233).

Thus, while the first investigation suggested examining the participants' own theoretical analysis of their CIs in order to understand the complexities underlying these configurations, the present study attends to such recommendation by examining these future teachers' theoretical reflections on their CIs and how they link to Costa Rica's current educational system. The study adopted a narrative research approach and used several validation measures to ensure credibility of findings (see methodology section).

Like the first study of 2017, this research was contextualized in a Comparative Linguistics (CL) course from an English teaching major (ETM) at the University of Costa Rica. The course examined the differences and similarities between the students' L1 (Spanish) and L2 (English) and how these could be used to prevent and deal with errors in English language teaching. Using reflective writing as a pedagogical tool, the course created a space for introspection into both, the participants' English learning experiences and their teaching practices since the majority were taking a teaching practicum by the time the study was run.

In this context, reflective writing as a means to prompt learning became paramount to the completion of the study. Sevilla and Gamboa (2017), echoing Ramsay, Barker, and Jones, 1999; Cisero, 2006; Mlynarczyk, 2006; Farrell, 2008; Khandelwal, 2009; Gorlewsk and Greene, 2011; Ryan 2011; Farrell, 2013; Purcell, 2013; Chang and Lin, 2014; Rutherford, Flin and Irwin, 2015; Walker, 2015; Schulz, Krautheim, Hackemann, Kreuzer, Kochs and Wagner, 2016; Kalman, Aulls, Rohar, and Godley, 2008 claimed that CIs and reflective writing have awakened an unprecedented interest as a way to aid language 
education. Hence, studies like the present one offer an opportunity to understand the students' own contemplations of their language learning journey.

Overall, this second paper makes several noteworthy contributions to the field of study and policy and decision-making in related instructional settings. In the forthcoming sections we present a review of relevant studies on critical incident analysis (henceforth, CIA) and reflective writing, the methodological framework, the data analysis and interpretation, and the conclusions and recommendations for further research.

\section{Literature Review}

To contextualize the study theoretically, this section outlines major studies on CIA and reflective writing and their applications to learning. The review is presented chronologically and includes research from various geographical locations and study areas.

Currently, CIA is conceived as a valuable qualitative research technique not only in language learning and teaching-related studies but also in other fields such as teacher education (Morey, Nakazawa \& Colving, 1997; Graham, 1997), sign language learning (Lang, Foster, Gustina, Mowl \& Liu, 1996), and medicine (Schulz, Krautheim, Hackemann, Kreuzer, Kochs \& Wagner, 2016; Rutherford, Flin \& Irwin, 2015). First prioneered in industrial psychology by John C. Flanagan (Corbally, 1956, p. 57), CIA today is at the core of educational research and practice, as we will briefly show in the lines ahead.

In 1999, Ramsay, Barker and Jones used critical incidents elicited through interviews to examine the academic adjustment and learning processes of international and local first-year students. Twenty local and international students reported positive and negative critical incidents which helped or hindered their learning during the first year. The researchers were able to consider the impact of particular teaching processes and discuss implications of teaching and learning in the first year. More recently in 2008, Farrell conducted a study in Singapore where he had eighteen trainee teachers in an English language teacher education course reflect on critical incidents that took place while teaching. The author concluded that CIA proved useful for trainee teachers. However, he warns that language educators should be aware that classification of such incidents into neat categories can be problematic and that critical incident tasks should be assigned carefully. All in all, Farrell concluded that if trainee teachers reflect on critical incidents that occur during class it is possible for them to unveil new understandings of the teaching and learning process.

Along the same lines, Khandelwal conducted a study in 2009 to identify teaching behaviors that differentiate excellent and very poor performance of 
undergraduate college teachers in India using the Critical Incident Technique (CIT) from the students' perspective. Two hundred thirty-seven critical incidents from sixty female students from three different undergraduate humanities courses at Lady Shri Ram College for Women, University of Delhi, were collected and analyzed qualitatively. Through the study it was possible to identify specific behaviors that faculty members can follow to yield improvement in teaching evaluations by students. It was also concluded that a list of critical behaviors may have implications in selection, training and performance evaluation of teachers. Finally, the researcher argues that the study underlines the robustness of the CIT in educational research.

Farrell (2013) carried out a study on "critical incident analysis that an ESL teacher in Canada revealed to her critical friend and how both used McCabe's (2002) narrative framework for analyzing an important critical incident that occurred in the teacher's class" (p. 79). The researcher concluded that teachers can impose order in their practices by analyzing critical incidents which can help develop the habit of engaging in reflective practice. Following this study, Walker (2015) used the CIT to assess ESL student satisfaction. He had 23 ESL students from a university English language center in Canada write about critical incidents that made them very satisfied and very dissatisfied with the service they were receiving from the center. He was able to draw conclusions regarding procedural, analytical, and student response issues with the CIT. The outcomes of his study "supported the view that information obtained through the CIT could assist ESL managers and teachers in developing and enhancing quality factors that more accurately reflect student expectations of the service" (Walker, 2015, p. 95). He goes on to claim that the CIT is a valuable tool to build understanding of this kind of issues since it is an explanatory methodology with potential to increase knowledge about previously unknown phenomena.

As for reflective writing, research has vindicated its value to prompt learning in a wide range of professional fields including -besides language instruction - the political sciences (Josefson, 2005), sociology teaching (Purcell, 2013), the teaching of science (Eiriksson, 1997), and biology (Balgopal and Montplaisir, 2011), to mention a few. Over and above this, reflective writing has been understood as a means to fostering permanent learning (Ryan, 2011, p. 99).

$184 \quad$ Along these lines, Cisero (2006) has studied "whether a reflective journal writing assignment would improve students' course performance" (p. 231). This research involved 166 students who completed the task (experimental group) and 317 students who did not (comparison group). The inquiry reveled that reflective journal writing may benefit the average student but not the good nor the struggling students. The author argues that "journal writing can only be effective in improving course performance if students make an effort to engage in reflective thinking, thereby making learning more meaningful" (p. 233). 
In the same year, Mlynarczyk (2006) ran a qualitative investigation that involved reflective journal writing in a four-year college in the U.S. Drawing from conclusions in her study, she argued that "all students- and especially basic writers- need to reflect on their reading using personal, expressive language in order to acquire genuine academic discourse" (p. 4). Two years later, Kalman, Aulls, Rohar and Godley explored how reflective writing was perceived and accomplished by a group of students in a physics course in Canada. Broadly, they concluded that "students understood that engaging in reflective writing enabled them to determine when they did not understand a concept as it was being read and that reflective writing promoted self-dialogue between the learner's prior knowledge and new concepts in the textbook" (2008, p. 74).

In 2011, Gorlewsk and Greene implemented a mixed-method action research using reflective writing as a vehicle to help students improve their writing skills in Georgia school. The authors argue that "structured opportunities for reflective writing allow students to polish their writings and to reflect actively on their written creations, while encouraging clearer and more honest writing products. They claim that reflective writing can transform students as they begin to incorporate metacognition, or thinking about their thinking, into their writing processes, as they simultaneously learn the curriculum" (p. 90). At a more general level, Chang and Lin (2014) studied the effects of reflective learning e-journals and how students used them to aid learning in an EFL college course using an experimental study design. Ninetyeight undergraduate students participated. The results suggest that students who used reflective learning e-journals outperformed students who did not in reading comprehension. It was also reported that students who used reflective learning e-journals improved their performance in an online course as well as their writing abilities.

So far, these are a few of the many studies that have used CIA and reflective writing to prompt and investigate learning in several areas of expertise. Although our review is by no means exhaustive, it helps frame our inquiry theoretically, and it invites the reader to delve into the full volume of literature on the subject.

\section{Methodology}

This section describes the methodological framework for data collection and the data analysis and interpretation that resulted from it. Following this, we present the data analysis and interpretation.

This investigation is based on narrative research, a methodology first adopted by disciplines such as literature, history and film, and then developed more strongly in education from the need to study "teacher reflection, teacher 
research, action research, and self-study [...]", as well as from a growing focus on "empowering teachers by giving them voices in the educational research process [...]" (Gay, Mills, \& Airasian, 2009, p. 384). In brief, narrative research uses a number of techniques such as "autobiographies, biographies, life writing, personal accounts, personal narratives, narrative interviews, [...] ethnobiographies, autoethnographies", and many others (ibid, p. 387). The current research is based mainly on autobiographical and biographical data produced by theoretical analyses of the CIs reported in Sevilla and Gamboa's 2017 study (cf. introduction of this paper).

Fieldwork was conducted from March through July 2015 and included 30 senior students enrolled in the ETM described previously in the introduction section. Participants came from mixed socio-economic backgrounds and had GPA scores ranging from 6 to 9.52 on a 1-10 scoring scale. The researchers used a chart of citing codes to safeguard student identity (see data analysis and interpretation section ahead).

Data were gathered from theoretical analyses of CIs previously narrated by the participants, and the articulation of such analysis in the light of Costa Rica's current public education system. Informants were thus able to tackle their own autobiographical accounts from a critical perspective using theoretical backup and the larger educational setting as a guide. Once data were collected, the researchers used the following data analysis and interpretation strategies suggested by Gay, Mills, and Airasian: (1) identifying possible themes from the data sets, (2) coding qualitative data, (3) finding interrelations amongst the codes, and (4) displaying findings (2009, p. 449).

Research validity was accomplished via three procedures. The researchers first conducted calibration sessions to agree on the major themes from the raw data. They then followed criteria established by Dey (1993) to counterbalance threats to validity. Such criteria included questions such as how reliable are those providing the data? What motivations may have influenced the participants' report? What biases may have influenced how observation was made and reported? (as cited by Gay, Mills, \& Airasian, 2009, p. 457). Lastly, participants were asked to read the reconstructions of their analyses to validate the investigators' accuracy in their analysis.

\section{Data Analysis and Interpretation}

This section looks into the data coming from the three major categories that emerged from the participants' theoretical analysis. Due to length limitations, the analysis will focus on the most recurrent themes only, leaving further details for future investigations. With the purpose of aiding clarity, we used citation codes throughout the section, as depicted in table 1 below. 
Table 1. Raw Data Citation Codes

\begin{tabular}{lll} 
Instrument Type & Data Source & Citing Code \\
\hline Theoretical Analyses & ETM Students & TA- P01-030 \\
\hline
\end{tabular}

Source: Researchers'own design

\section{The Monolingual Perspective of Instruction and Assessment}

For many decades, the language classroom has worked under the maxim that students' second language (L2) proficiency should be assessed against the standards of a target first language (L1). In recent academic discussions, this view has been referred to as the monolingual perspective - or bias - and has sparked considerable theoretical attention and criticism (see May, 2014; Fallas and Dillard, 2015; and Fallas, 2016). These theoretical developments, fortified by the ever-growing consolidation of Critical Applied Linguistics (CAL), are challenging the long-held monolingual view of language instruction and assessment and allowing for alternative ways to conceive theory and practice. In the data sources we examined, a great area of the students' analysis revolved around this very subject. After a review on Ferris' description of global and local errors (2013, p. 88), P11 and P12 make the following claim:

The problem we find with this is that at all times we were being measured from the angle of the native-like scale. Even today, we understand errors are being assessed in such a way that students are expected to produce the target language as if they were native speakers of the new language. In other words, L2 learning must duplicate the target language to its fullest rather than to be a means for communication. In our narratives, the locus of attention was never communication given that the relevance of errors laid in a local level. As students of English and soon-to-be teachers, we do not think students should be measured in relation to how much they approximate to a native speaker because we are not dealing with simultaneous bilinguals, but emerging bilinguals at best (TA-P11 and TA-P12, sic).

Strikingly, much of what these participants are saying coincides with what Fallas would argue in his 2016 paper-about one year following the students' theoretical analyses. Certainly, this goes without saying that the students had the upper hand in the discussion, but it is an exceptional fact that both participants and the scholar were synchronized over a subject that even today may seem so alien to many EFL researchers. Later on in their analysis, these same participants bring this statement forward: 
English teachers should avoid measuring students with a native-like scale. Corder (1971) describes the notion of language transfer when features of the L1 are present in the L2. It is only natural to find language transfer in the Costa Rican EFL context. Thus, the focus of feedback should be on getting the message across rather than torturing students with native-like pronunciation or intonation at early stages. (TA-P11 and TA-P12, sic).

The students conclude their discussion by highlighting that "student's voices need to be heard. They need the experience the satisfaction of being listened to as people with opinions, feelings, and experience", and that the reflection space offered through this research was a rewarding enterprise: "We appreciate the space created for us to reflect upon these matters for we have no only fund the way to overcome the Achilles Hill in writing but also we have enjoyed the ride in the English Roller Coaster" (TA-P11 and TA-P12, sic).

\section{The Need to Tolerate Errors}

As early as 1990, authors such as Lightbown and Spada argued that the change from a focus on form to an emphasis on the communication and understanding of meaning through language has resulted in a greater tolerance for error in learner's speech. This has led many language teachers to an understanding that language accuracy might very well be sacrificed as a tradeoff for communicability. Such an assertion matches participant 06's reflection, which reads:

[...] mistakes are an essential part of the processes behind learning a second language, and therefore mistaking really makes us realize that our knowledge is being fostered and improved. [...], we, as future teachers of a foreign language, should encourage motivate learners to use the language and to get acquainted with it. Also, we ought to avoid temptation of correcting everything we might find wrong in a student's utterance; rather try to enhance his/her fluency while speaking by improving their desire to say what s/he would like to say" (TA-P06, sic).

This implies that not only is P06 quite aware that mistakes are an indicator that learning is taking place, but also that it is a teacher's responsibility to account for that in their teaching practice. From this same informant, we later on get the perspective that mistakes are not only part of the language learning process, but more broadly part of our human nature: "Carl James in his book 'Errors in Language Learning and Use: Exploring Error Analysis', states that errors are unique to humans, as we are not only sapiens but also homo errans" (TA-P06, sic). He adds that committing errors, in Carl James' view, is "the very pinnacle of human uniqueness (James, 1998, P.1)", and that it is even more so in the specific context of language learning (TA-P06). His own implicit 
remark on the need to tolerate errors surfaces when he explains: "Because I never did well in English in high-school, I was forced to start from scratch at the university, and this set off challenged me to try and fail a zillion times" (ibid, sic).

Nonetheless these claims, this participant clarifies that as normal as mistakes can be, teachers must not get to the extreme of ignoring them altogether. He cites Tebbit's 1985 argument on the dangers of extreme tolerance towards mistakes:

We've allowed so many standards to slip... Teachers weren't bothering to teach kids to spell and to punctuate properly... If you allow standards to slip to the stage where good English is no better than bad English, where people turn up filthy... at school... All those things tend to cause people to have no standards at all, and once you lose standards then there's no imperative to stay out of crime (Tebbitt, 1985). (TA-P06, sic)

He winds up his theoretical analysis by highlighting the importance of appropriate feedback methods for effective language learning: "The professors' role is to guide, encourage, help and engage the learners' attempts to using a target language, not to discourage them by insulting or pushing their performance into a hurry, consequently, making mistakes" (TA-P6, sic).

\section{The Need for Better Corrective Feedback Methods}

The notion of corrective feedback has been the subject of study for many years now. Abaya (2014) argues that this tendency was significantly propelled by "Hendrickson's study of 1978 in which he questioned if errors should be corrected and if so which ones, when and how errors should be corrected." (p. 5). She goes on to argue that "corrective feedback remains one of the contentious issues in second language teaching and that there is no consensus in its application" (p. 5). Arguably, corrective feedback is an inherent part of second and foreign language pedagogy that is highly influenced by teachers' beliefs, which often conflict with learners' perspectives (ibid). This issue was eloquently illustrated by P24 and P25 assertions:

However, as Ramírez (2007) explains that, "sometimes [...] teachers are not familiar with the most appropriate way in which they should correct students in order not to affect their motivation to participate" (p. 106). The teacher's lack of expertise in creating the right environment in terms of error correction is a crucial matter that might impact the learning of a second language. In Costa Rica, for example, teachers have been wrongly taught that the best way to correct students is by pointing errors immediately, with no reflection on the way the feedback is given and taken by students (Ramírez, 2007) (TA-P24 and TA-P25, sic). 
Along the same lines, P05 states:

In my opinion there should be a general knowledge from educators about key aspects in error corrections, in order for them to take them into consideration when teaching. One of my recommendations is to respect all your students as you want them to respect you; equality is one of the best values that should always prevail (TA-P05, sic).

From this perspective, the need for better corrective feedback leans toward both, technical expertise on the subject and affective considerations as well. Instinctively perhaps, he is aware that practical knowledge in isolation does not suffice in gearing corrective feedback in the right direction and acknowledges the place of the psycho-affective domain in the issue at stake. This is again reinforced by P24 and P25 when they argue: "the process of correct errors can affect students emotionally, hence their ability to speak a foreign language $[\ldots]$ the harsh way professors gave us feedback, made us not wanting to have an active role in classes anymore (TA-P24 and CI-P25, sic).

In an analysis of the role of competence (what a student knows) and performance (the way competence is demonstrated) in teachers' choice of corrective feedback, P20 and P21 make the following point:

One of the most commonly held assumptions by students and teachers alike is that competence and performance are the same. Thus, when a student is performing, teachers usually pay more attention than necessary to grammar mistakes, intonation, and self-confidence (TA- P20 and TAP21).

These participants further explain that when teachers do not differentiate between these constructs, the result is a tendency to overemphasize isolated errors and ignore the full wealth of knowledge (competence) a student has: "Some professors and students think that just because of an isolated mistake, the learner is not capable of learning the language" (ibid). They warn that the outcome of this lack of knowledge is twofold: It undermines the significance of the psycho-emotional domain of the learner on the one hand, and it leads to academic frustration on the other (compare Sevilla and Gamboa, 2017, for expansion on this). Upon concluding their analysis, these two participants highlight the need to deter academic frustration and tensions caused by faulty corrective feedback: "As future English teachers, it is essential to break the pattern of academic frustration caused by inadequate teaching techniques and tense class atmosphere. An educator has to encourage students not only to learn but also to respect others" (ibid). 


\section{Conclusions}

As stated earlier in this paper, our study purported to examine future teachers' theoretical reflections on their CIs and how they link to our current educational system. Upon its completion, we have arrived at the following major conclusions: First, spaces for reflection need to be created within the EFL classroom so that students' voices are heard. Second, both instruction and assessment need to be tackled not so much from the native speaker angle but rather from the learner language perspective. Third, because mistakes are both, inherent to foreign language learning and an indicator of language development, more tolerance to learner errors need to be exercised on the part of language teachers. Therefore, language instructors should inform their teaching and assessment practices by such principles. Last, teachers need to be well trained in the field of corrective feedback so that they foster language learning rather than disappointment and demotivation.

Even though findings yield solid conclusions, there are limitations which need to be acknowledged and dealt with in further research. Our study was limited to a small sample population and thus findings can only account for what was done within the constraints of it, which implies that results cannot be transferred to other settings. Additionally, the realms of corrective feedback are a double-face coin, with the learners' views on one side and those of the teachers on the other. Further research needs to be done in the same context considering the teachers' voices to capture the perspectives of current instructors on the issue. The scope and depth of the study stands as our last limitation, which restricts generalizability. Only further research will prove whether and to what degree our findings are true for all contexts.

In terms of implications, findings help bridge knowledge gaps from Gamboa and Sevilla's 2017 paper on critical incidents, reflective writing, and future teachers' professional identities. Despite their exploratory nature, the methods from our two papers could be adopted in other language programs and used as a basis for best practices and policy making. We coincide with Merriam and Tisdell's (2016) claim that qualitative inquiries can often assist moderate generalizations and suggest courses of action to benefit the individuals involved. After all, it is the voices of future teachers that speak up from the current inquiry. Failing to listen to these claims is, we presume, a luxury no responsible ELT program would want to afford. 


\section{References}

Abaya, R. (2014). Corrective feedback in English Language Teaching and Learning: Which Way to Go? 10 (2), 5-12. https://pdfs.semanticscholar.org/ b3ce/846ab0561c5d1c5d3baff6fed463b4fa3bb0.pdf

Balgopal, M. M., \& Montplaisir, L. M. (2011). Meaning making: What reflective essays reveal about biology students' conceptions about natural selection. Instructional Science, 39 (2), 137-169. https://www.jstor.org/ stable/23882852?seq=1\#page scan tab contents

Chang M. \& Lin M. (2014). The Effect of Reflective Learning E-journals on Reading Comprehension and Communication in Language Learning. Computers and Education, 71, 124-132.

Cisero, C. A. (2006). Does Reflective Journal Writing Improve Course Performance? College Teaching, 54 (2), 231-236. https://www.jstor.org/ stable/27559272?seq=1\#page_scan_tab_contents

Corbally, J. E. (1956). The Critical Incident Technique in Educational Research. Educational Research Bulletin, 35 (3), 57-62.

Dey, Ian (1993). Qualitative Data Analysis: A User-friendly Guide for Social Sciences. London and New York: Routledge Taylor \& Francis Group.

Eiriksson, S. (1997). Preservice Teachers Perceived Constraints of Teaching Science in the Elementary Classroom. Journal of Elementary Science Education, 9(2), 18-27. https://www.jstor.org/ stable/43155662? seq=1\#page_scan tab_contents

Fallas, C., \& Dillard, E. (2015). Professors' and Students' Conflicting Views about Translanguaging in the EFL Classroom: Dismantling the Monolingual Bias. Revista de Lenguas Modernas, 23, 301-328. http://revistas.ucr.ac.cr/ index.php/rlm/article/download/22355/22512

Fallas, C. (2016). Challenging the Monolingual Bias in EFL Programs: Towards a Bilingual Approach to L2 Learning. Revista de Lenguas Modernas, 24, 249-366. http://revistas.ucr.ac.cr/index.php/rlm/article/ download/24627/25259

192 Farrell, T. (2013). Critical Incident Analysis through Narrative Practice: A Case Study. Iranian Journal of language Teaching Research, 1(1), 79 - 89. Retrieved from: https://files.eric.ed.gov/fulltext/EJ1127432.pdf

Farrell, T. C. (2008). Critical incidents in ELT initial teacher training. ELT Journal: English Language Teaching Journal, 62(1), 3-10. https://doi. org/10.1093/elt/ccm072 
Freeman, D. (1998). Doing Teacher Research: From Inquiry to Understanding. Pacific Grove: Heinle \& Heinle.

Gay, L.R., Mills, G.E., \& Airasian, P. (2009). Educational Research: Competencies for Analysis and Applications. New Jersey: Pearson Education, Inc.

Gorlewski, J., \& Greene, K. (2011). Research for the Classroom: The Power of Reflective Writing. The English Journal, 100 (4), 90-93. http://www.jstor. org/stable/23047788

Graham, J. (1997). Pedagogical Growth of Two Student Teachers in Art as Revealed in their Journal Entries Reflecting Critical Incidents in the Classroom. Visual Arts Research, 23 (1), 1-30. http://www.jstor.org/ stable/20715891

Josefson, J. (2005). Don't Argue, Reflect! Reflections on Introducing Reflective Writing into Political Science Courses. PS: Political Science and Politics, 38 (4), 763-767. http://www.jstor.org/stable/30044366

Kalman, C., Aulls, M. W., Rohar, S., \& Godley, J. (2008). Students' Perceptions of Reflective Writing as a Tool for Exploring an Introductory Textbook. Journal of College Science Teaching, 37 (4), 74-81. http://www. jstor.org/stable/42992781

Khandelwal, K. (2009). Effective Teaching Behaviors in the College Classroom: A Critical Incident Technique from Students' Perspective. International Journal of Teaching and Learning in Higher Education, 21 (3), 299-309. http://www.isetl.org/ijtlhe/pdf/IJTLHE597.pdf

Khandelwal, K. A. (2009). Effective Teaching Behaviors in the College Classroom: A Critical Incident Technique from Students' Perspective. International Journal of Teaching and Learning in Higher Education, 21 (3), 299-309.

Lang, H. G., Foster, S., Gustina, D., Mowl, G., \& Liu, Y. (1996). Motivational Factors in Learning American Sign Language. Journal of Deaf Studies and Deaf Education, 1 (3), 202-212. http://www.jstor.org/stable/23802936

Lightbown, P. M., \& Spada, N. (1990). Focus-on-Form and Corrective Feedback in Communicative Language Teaching: Effects on Second Language Learning. Studies in Second Language Acquisition, 12, 429-448.

May, S. (2014). The Multilingual Turn: Implications for SLA, TESOL and Bilingual Education. New York: Routledge.

Merriam, S. B., \& Tisdell, E. J. (2016). Qualitative research: A guide to design and implementation. San Francisco, CA: Jossey-Bass. 
Mlynarczyk, R. W. (2006). Personal and Academic Writing: Revisiting the Debate. Journal of Basic Writing, 25 (1), 4-25. https://www.jstor.org/ stable/43444074?seq=1\#page scan tab contents

Morey, A. I., Nakazawa, K., Colvin, C. (1997). Japanese and American Student Teacher Voices: A Comparative Study of Critical Incidents. Peabody Journal of Education, 72 (1), 203-214. https://www.jstor.org/ stable/1493268?seq=1\#page scan tab contents

Purcell, D. (2013). Sociology, Teaching, and Reflective Practice: Using Writing to Improve. Teaching Sociology, 41 (1), 5-19. https://www.jstor. org/stable/41725576?seq=1\#page_scan_tab_contents

Rutherford, J. S., Flin, R., \& Irwin, A. (2015). The non-technical skills used by anaesthetic technicians in critical incidents reported to the Australian Incident Monitoring System between 2002 and 2008. Anaesthesia \& Intensive Care, 43 (4), 512-517.

Ryan, M. (2011). Improving reflective writing in higher education: a social semiotic perspective. Teaching in Higher Education, 16(1), 99-111. https:// doi.org/10.1080/13562517.2010.507311

Schulz, C. M., Krautheim, V., Hackemann, A., Kreuzer, M., Kochs, E. F., \& Wagner, K. J. (2016). Situation awareness errors in anesthesia and critical care in 200 cases of a critical incident reporting system. BMC Anesthesiology, 161-10. https://doi.org/10.1186/s12871-016-0172-7

Sevilla, Henry, \& Gamboa, Roy. (2017). Critical Incidents, Reflective Writing, and Future Teachers' Professional Identities. Revista de Lenguas Modernas, 26, 233-255. https://revistas.ucr.ac.cr/index.php/rlm/article/view/29971

Ramsay, S., Barker, M., \& Jones, E.. (1999). Academic Adjustment and Learning Processes: a comparison of international and local students in first-year university. Higher Education Research and Development. https:// doi.org/10.1080/0729436990180110

Tripp, D. (1993). Critical Incidents in Teaching: Developing Professional Judgement. London: Routledge.

194 Walker, J. (2015). Perspectives: Using Critical Incidents to Understand ESL Student Satisfaction. TESL Canada Journal, 32 (2), 95-111. 


\section{Authors}

*Henry Sevilla-Morales M.A. has been an EFL instructor for 13 years at the elementary, secondary, and higher education levels. He is an Associate Professor at the National University of Costa Rica and holds over 20 publications including research papers, short stories, poems, and news articles. His investigations have been presented in more than 30 national and international conferences, and his papers appear in various scientific journals and conference proceedings in Costa Rica, Colombia, and the United States. His current research agenda includes topics such as learner autonomy, authentic assessment, testing washback, reflective writing, and translation studies. For a preliminary list of academic publications, visit https://www.researchgate.net/ profile/Henry_Sevilla_Morales.

ORCID: https://orcid.org/0000-0003-4040-8062

Roy Gamboa-Mena has been an EFL professor for 25 years at the higher education level. He is a tenured professor of English at the Universidad de Costa Rica. His current research areas include reflective writing, learner autonomy, and ELT materials development and evaluation. His research has been presented in several national and international conferences and published in several journals and conference proceedings.

ORCID: https://orcid.org/0000-0001-5356-7738

How to reference this article: Sevilla-Morales, H., \& Gamboa-Mena, R. (2019). Break the Negative Feedback Chains: Future Teachers Speak Up. GiST Education and Learning Research Journal, 18, 180-197. https://doi.org/10.26817/16925777.420 


\section{Appendix}

\section{Appendix 1: Instructions for the Critical Incident Analysis}

Objective: to write a solid analysis of the relationships between your critical incidents and: (1) the professional literature on the field of Contrastive Linguistics and (b) the interpretation of the incidents in the context of English teaching in Costa Rica.

Instructions: Now that you're done with the narration of your critical incident, time has come for you to do the academic work. Consider (some of) the following elements:

- a theoretical discussion of your incident using at least five academic sources (very important, not optional)

- the significance of the incidents for you as English learners,

- $\quad$ some assumptions about language that have been challenged or reinforced upon experiencing the incident,

- what you will do if you are faced with a similar situation in the future,

- $\quad$ how the two incidents interrelate with each other (very important, not optional), and

- an interpretation of the incidents in light of the teaching of English in Costa Rica (very important, not optional).

\section{NOTES:}

- If you are working in pairs, remember to find relationships between the two incidents.

- Follow the article by Sevilla in order to help you articulate the theoretical discussion of your incidents.

- Start thinking about your conclusions, which basically are a proposal in order to deal with these incidents in the teaching-learning setting.

Designed for IO-5320, Contrastive Linguistics (April 2015) 


\section{Appendix 2: Informed Consent Letter}

University of Costa Rica

Western Branch

Department of Philosophy and Arts

\section{Dear student/participant:}

This is a request for consent to participate in a research study. In so doing, the researchers seek to systematize your analysis of the critical incidents you wrote for the course IO-5320 Contrastive Linguistics. The general goal of the study is to study your theoretical analyses and how they connect to our current public education system. In order to ensure anonymity, the researchers will preserve your confidentiality by means of the following:

- Assigning code names or numbers for participants so that their real identities are kept anonymous.

- Keeping data sources in a locked file cabinet in the personal possession of the researchers.

- $\quad$ Sharing a copy of the final manuscript before it is sent for publication upon request.

Your participation in this study is voluntary. If you decide to participate, you will be asked to sign this letter of consent. After you sign the letter, you are still free to withdraw, and this will not affect the relationship you have with the professors-researchers.

It is our hope to use the results of this research to publish at least one article on the subject. Feel free to contact us in person or via e-mail at henrysevilla@gmail.com; gamboa.roy@gmail.com if you have any more questions regarding this research.

Yours, truly,

M.A. Henry Sevilla Morales

Researcher

Mag. Roy Gamboa Mena

Researcher

Participant's Name (please also sign above): 